\title{
Effect of thermal processing on the protein value of double-low rapeseed products 2. Effect of processing stages in the oil plant and of toasting in laboratory conditions
}

\section{W. Grala, Barbara Pastuszewska, Stefania Smulikowska, Lucyna Buraczewska and Jolanta Gdala}

\author{
The Kielanowski Institute of Animal Physiology and Nutrition, Polish Academy of Sciences \\ 05-110 Jablonna, Poland
}

(Received 26 January 1994; accepted 21 February 1994)

\begin{abstract}
The effects of two main processing stages (cooking and toasting) in extraction plant on the nutritional value of double-low rapeseed products were studied. Raw seeds and cooked cake taken from the oil factory were defatted and compared with toasted rapeseed meal in $\mathrm{N}$ balance/growth performance experiment with rats and in growth performance experiment with brolier chickens. Moreover, the effect of temperature and time of heating in the laboratory $\left(100\right.$ and $120^{\circ} \mathrm{C}$ for 10,20 or $30 \mathrm{~min}$ ) on protein value of defatted expeller cake was also studied in $\mathrm{N}$ balance/growth perfomance experiment with rats.

The toasting process had the most depressing effect on the content of total and available lysine and of glucosinolates as compared to their level in the seeds. The rats and chickens fed with diet containing toasted rapeseed meal performed better than those fed with dicts containing non-heated defatted rape seeds or cooked and defatted cake. The toasting process reduced harmful effect of rape seed on $(\mathrm{P} \leqslant 0.01)$ the thyroid and liver weights of rats and thyroid weight of chickens.

Increasing temperature and time of laboratory heating resulted in linear decrease $(P \leqslant 0.001)$ in lysine, available lysine and glucosinolate contents as well as protein value of defatted cake for rats (TD, BV and NPU). However, the decrease in lysine content was much more dependent on the increase of temperature than on the prolongation of heating. The performance of rats (body weight gain, feed utilization) was influenced $(P \leqslant 0.01)$ by both factors. Feed intake and weight gain of rats decreasd as time of heating increased but only at higher temperature $\left(120^{\circ} \mathrm{C}\right)$. The thyroid weight linearly deceased $(P \leqslant 0.01)$ as temperature increased.

It seems that toasting of double-low RSM in mild conditions is necessary to eliminate the negative infuence of residual glucosinolates on the animal performance.
\end{abstract}

KEY WORDS: double-low rapeseed meal, processing, heating, protein value, chickens, rats 


\section{INTRODUCTION}

Previous studies by Grala et al. (1994) showed that the toasting temperature was not the only technological parameter which should be modified to improve the protein value of double-low rapeseed meal produced by Polish oil industry. It was found that protein value of rapeseed meal was negatively influenced by the increase of temperature in one plant, while toasting at even higher temperature in another one did not decrease protein value or pig performance. It was suggested that other parameters of processing such as water content and duration of toasting and/or cooking may affect nutritional value of rapeseed meal. During processing rape seed is heated at least three times: during conditioning-cooking, expelling and desolventizing-toasting (Pickard et al., 1986; Niewiadomski, 1990). Due to various reasons the conditions of processing are not always stable and the meal is often over-heated. It is very well known that too high temperature damages protein and amino acids, lysine in particular (Anderson-Hafermann et al., 1993) and lowers their availability for animals.

The objectives of the present study was to establish: A - the effect of consecutive plant processing stages involving heat treatment, that is cooking and toasting, on protein value of resulting rapeseed products, expeller cake and oil meal, respectively, and B - the effect of temperature and time of laboratory heating on protein value of defatted expeller cake (simulation of toasting process).

\section{MATERIAL AND METHODS}

\section{A. Effect of cooking and toasting}

\section{Materials}

Rape seeds (Brassica napus, L., var. Jantar) and their processed products were obtained from the same oil factory where the samples of rapeseed meal were taken for previous study by Grala et al. (1994).

The samples taken from consecutive processing steps were: 1) full-fat rape seeds sampled prior to flaking; 2) expeller cake sampled after initial flaking, cooked at $85^{\circ} \mathrm{C}$, but prior to solvent-extraction; 3) rapeseed meal (RSM), solvent-extracted and toasted at $100^{\circ} \mathrm{C}$. The first two products were then defatted with petrol at temperature of 45 to $50^{\circ} \mathrm{C}$ and were coded as: defatted seeds and defatted cake, respectively. The effect of consecutive processing stages on protein value of defatted seeds, defatted cake and RSM was evaluated on rats and chickens. 


\section{Diets and animals}

Experiment 1. In the $\mathrm{N}$ balance trial with rats $\mathrm{TD}, \mathrm{BV}$ and NPU were determined, using Thomas-Mitchell method (NRC, 1967). The rapeseed products (seeds, cake and RSM) were evaluated as the only protein source in semi-purified diets providing about $10 \%$ of crude protein $(\mathrm{CP})$. Each diet was fed $\left(11 \mathrm{~g} / \mathrm{rat} /\right.$ day) to eight 29-days old male rats from the $\mathrm{I}_{\mathrm{fz}}: \mathrm{JAZ}$ coiony. After 10 days of balance trial the rats were maintained during next 21 days on the same diets offered to appetite. Feed intake (FI, g/rat/31 days), body weight gain (BWG, g/rat/ 31 days) and feed conversion (FC, g feed/g BGW) were measured. At the end of the experiment the rats were killed and the thyroid and liver weights were recorded.

Experiment 2. The experiment was conducted to compare the nutritional value of protein of defatted seeds, defatted cake and RSM for chickens. Male Astra-B broiler chickens aged 7 days were divided into three groups of 32 birds each and kept for 4 weeks in cages in pairs. Birds were offered the wheat-based diets $(20 \% \mathrm{CP} / \mathrm{DM})$ containing $25.5-27 \%$ of rapeseed products. Pelleted diets and water were provided to appetite. FI ( $\mathrm{kg} / 4$ weeks), BGW (g/4 weeks) and FC ( $\mathrm{g} / \mathrm{g}$ BGW) were determined. The thyroid and liver weights were recorded at the end of experiment.

\section{B. Effects of temperature and time of heating}

\section{Materials}

The effects of time and temperature of toasting on the protein value of rapeseed meal was studied in laboratory, where the toasting process was imitated by heating samples in an autoclave. Defatted cake was used to prepare the rapeseed flours differing in duration and temperature of toasting. The samples of defatted cake were placed on sieves ( $5 \mathrm{~cm}$ thin layers) and then autoclaved at $100^{\circ} \mathrm{C}$ (pressure $20 \mathrm{kPa}$ ) or $120^{\circ} \mathrm{C}$ (pressure $100 \mathrm{kPa}$ ) for 10,20 and $30 \mathrm{~min}$. The autoclaved defatted cake was named as ,heated cake". Temperature of 100 and $120^{\circ} \mathrm{C}$ was chosen, since such toasting temperatures were applied in the oil plant (Grala et al., 1994).

\section{Diets and animals}

Experiment 3. The experiment with rats was designed and carried out similarly to Experiment 1 and the same features were measured. 


\section{Chemical analyses}

The rapeseed products, diets and samples of faeces and urine were analyzed for nitrogen by Kjeldahl method. Available lysine was analyzed according to the Carpenter method modified by Booth (1971) and glucosinolates were determined according to the Youngs-Watter method modified by Byczyńska (1971).

\section{Statistical analysis}

Results were statistically analyzed using one-way ANOVA test generated by STATGRAPHICS ver. 2.1 statistical package. Differences between treatment means were evaluated using the Duncan test (Expt. 1,3) and the least significant difference test (LSD) (Expt. 2). Single and multiple linear regression analyses were used to evaluate pattern of response of measured traits to experimental factors.

\section{RESULTS}

Contents of protein, lysine, available lysine and glucosinolates in rapeseed products

The effects of plant processing steps on the chemical composition of rapeseed products are shown in Table 1 . There was no effect of cooking and toasting on $\mathrm{CP}$ content in the products. Contents of lysine, available lysine and glucosinolates decreased as processing progressed. Cooking and toasting decreased lysine content from 6.10 in seeds to 5.77 and $5.64 \mathrm{~g} / 16 \mathrm{~g} \mathrm{~N}$, respectively. Available lysine and glucosinolates were reduced mainly by toasting $(5.08,5.00,4.42 \mathrm{~g} / 16 \mathrm{~g} \mathrm{~N}$ and $17.7,17.6,4.7 \mu \mathrm{M} / \mathrm{g}$ fat-free dry matter, respectively).

Increasing both temperature and time of heating resulted in linear decrease $(P \leqslant 0.001)$ in lysine, available lysine and glucosinolate contents in the heated cake (Table 2). However, the content of lysine was much more affected by temperature $(P \leqslant 0.01)$ than by time of heating $(P>0.05)$. After heating at $100^{\circ} \mathrm{C}$ for 10,20 and $30 \mathrm{~min}$ lysine content in the cake was $5.83,5.71$ and 5.79 and available lysine $4.93,4.78$ and $4.56 \mathrm{~g} / 16 \mathrm{~g} \mathrm{~N}$, respectively. Heating at $120^{\circ} \mathrm{C}$ reduced lysine content to $5.35,5.43$ and 5.33 and available lysine content to 4.60 , 4.00 and $3.60 \mathrm{~g} / 16 \mathrm{~g} \mathrm{~N}$ after 10,20 and $30 \mathrm{~min}$, respectively.

High temperature had a very destructive effect on glucosinolates; heating at $100^{\circ} \mathrm{C}$ for $30 \mathrm{~min}$ decreased glucosinolates to $70 \%$ of their initial level while heating at $120^{\circ} \mathrm{C}$ for $30 \mathrm{~min}$ reduced them almost to zero. 
Effect of processing stages on the content of lysine, available lysine and glucosinolates in rapeseed products

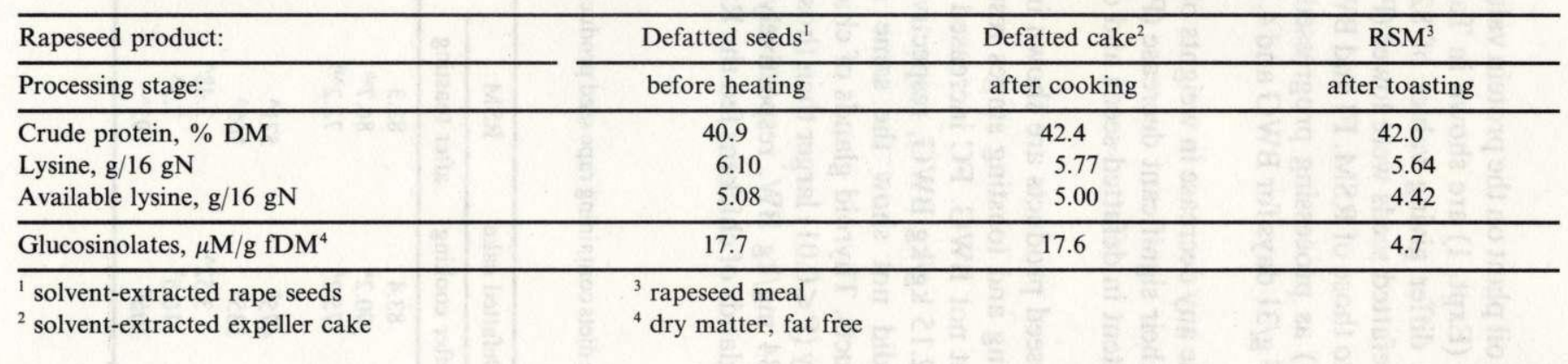

Effects of temperature and time of heating on content of lysine, available lysine and glucosinolates in defatted cake (heated cake)

TABLE 2

\begin{tabular}{|c|c|c|c|c|c|c|c|c|c|}
\hline \multirow{2}{*}{$\begin{array}{l}\text { Temperature, }{ }^{\circ} \mathrm{C} \\
\text { Time, min: }\end{array}$} & \multirow{2}{*}{10} & \multicolumn{2}{|l|}{100} & \multicolumn{3}{|c|}{120} & \multicolumn{2}{|c|}{ Factor $^{1}$} & \multirow[t]{2}{*}{$\mathrm{Txt}^{2}$} \\
\hline & & 20 & 30 & 10 & 20 & 30 & $\mathrm{~T}$ & $\mathrm{t}$ & \\
\hline Lysine, $\mathrm{g} / 16 \mathrm{gN}$ & 5.83 & 5.71 & 5.79 & 5.35 & 5.43 & 5.33 & $* *$ & NS & $*$ \\
\hline Available lysine, $\mathrm{g} / 16 \mathrm{gN}$ & 4.93 & 4.78 & 4.56 & 4.60 & 4.00 & 3.60 & $* *$ & $* *$ & $* *$ \\
\hline Glucosinolates, $\mu \mathrm{M} / \mathrm{g}$ fDM & 15.4 & 14.1 & 12.3 & 9.2 & 3.0 & 0.3 & $* *$ & $* *$ & ** \\
\hline
\end{tabular}

${ }^{1}$ factors: $\mathrm{T}=$ temperature, $\mathrm{t}=$ time

${ }^{2}$ interaction of temperature and time

** $-\mathrm{P} \leqslant 0.01$

* $\quad-\mathrm{P} \leqslant 0.05$

NS - not significant. The linear effect $(\mathrm{P} \leqslant 0.001)$ of increasing temperature and time of heating on lysine, available lysine and glucosinolate contents in extracted cake was observed 


\section{Protein value of rapeseed products}

The effects of processing stages in the oil plant on the protein value of defatted seeds, defatted cake and RSM for rats (Expt. 1) are shown in Table 3. TD of protein of evaluated products did not differ giving values of $82.1,83.4$ and $83.3 \%$, respectively. BV and NPU of defatted seeds were lower $(P \leqslant 0.05)$ than those of defatted cake and were similar to those of RSM. FI and BWG increased $(\mathrm{P} \leqslant 0.01)$, and $\mathrm{FC}$ decreased $(\mathrm{P} \leqslant 0.01)$ as processing progressed. The values were: $417,475,571 \mathrm{~g}$ for FI; $98,135,165 \mathrm{~g} / 31$ days for $\mathrm{BWG}$ and 4.28, 3.52, 3.48 for $\mathrm{FC}$.

Cooking (defatted cake) did not cause any decrease in weights of thyroid and liver while toasting (RSM) resulted in their significant decrease $(P \leqslant 0.01)$. The results correspond to glucosinolate content in defatted seeds and defatted cake (Table 1).

Results of feeding chickens the rapeseed products are shown in Table 4. In contrast to results with rats, the cooking and toasting stages resulted only in significant increase $(P \leqslant 0.01)$ in FI, but not BWG. FC increased $(P \leqslant 0.05)$ as processing progressed $(2.07,2.12$ and $2.15 \mathrm{~kg} / \mathrm{kg} \mathrm{BWG}$, respectively).

The thyroid weights of chickens did not show the same regularity as glucosinolate content in rapeseed products. Thyroid glands of chickens fed the diet with defatted cake were significantly $(P \leqslant 0.01)$ larger then those of birds fed the diet with defatted seeds ( $217 \mathrm{vs} 284 \mathrm{mg} / \mathrm{kg} \mathrm{BW}$, respectively), in spite of similar glucosinolate content. Thyroid glands of chickens fed the RSM diet were

TABLE 3

Protein value and performance of rats fed with the dicts containing rape seed products obtained from different processing stages (Experiment 1)

\begin{tabular}{|c|c|c|c|c|}
\hline \multirow{2}{*}{$\frac{\text { Diet with: }}{\text { Processing stage: }}$} & Defatted seeds & Defatted cake & RSM & \multirow{2}{*}{ SE } \\
\hline & before heating & after cooking & after toasting & \\
\hline TD $\%$ & 82.1 & 83.4 & 83.3 & 0.31 \\
\hline BV & $85.1^{\mathrm{b}}$ & $90.2^{\mathrm{a}}$ & $86.7^{\mathrm{ab}}$ & 0.63 \\
\hline NPU, \% & $69.8^{\mathrm{B}}$ & $75.2^{\mathrm{A}}$ & $72.2^{\mathrm{AB}}$ & 0.48 \\
\hline Feed intake, g/31 days & $417^{8}$ & $475^{\mathrm{B}}$ & $571^{\mathrm{A}}$ & 8.81 \\
\hline Body weight gain, g/31 days & $98^{\mathrm{C}}$ & $135^{\mathrm{B}}$ & $165^{\mathrm{A}}$ & 2.94 \\
\hline Feed conversion, $\mathrm{g} / \mathrm{g}$ & $4.28^{\mathrm{B}}$ & $3.52^{\mathrm{A}}$ & $3.48^{\mathrm{A}}$ & 0.03 \\
\hline Thyroid, $\mathrm{mg} / 100 \mathrm{~g} \mathrm{BW}^{5}$ & $15.9^{8}$ & $16.5^{\mathrm{B}}$ & $7.5^{\mathrm{A}}$ & 0.67 \\
\hline Liver, mg/g Bit & $116^{\mathrm{B}}$ & $105^{\theta}$ & $92^{\wedge}$ & 1.81 \\
\hline
\end{tabular}

${ }^{\text {ab }}$ differences in rows significant at $\mathrm{P} \leqslant 0.05$

${ }^{\mathrm{AH}}$ differences in rows significant at $\mathrm{P} \leqslant 0.01$ 
smaller $(93 \mathrm{mg} / \mathrm{kg} \mathrm{BW} ; \mathbf{P} \leqslant 0.01)$ than those of birds fed the diets with defatted seeds $(217 \mathrm{mg})$ or defatted cake $(284 \mathrm{mg})$. Liver weights of chickens did not differ among the groups.

The effect of temperature and time of heating in laboratory conditions on protein value of the cake for rats is shown in Table 5. TD of protein was not influenced by heating at $100^{\circ} \mathrm{C}$ while it decreased progressively by heating at $120^{\circ} \mathrm{C}$ for 10,20 and $30 \mathrm{~min}(82.2,80.8$ and $79.5 \%$, respectively). BV was not affected by heating at $100^{\circ} \mathrm{C}$ for 10 and $20 \mathrm{~min}$ ( 90.4 and 89.9 , respectively) while prolongation the time to $30 \mathrm{~min}$ at $120^{\circ} \mathrm{C}$ depressed $\mathrm{BV}$ progressively to 80.3 .

Both factors affected negatively $(P \leqslant 0.01)$ FI and BWG as well as FC $(\mathbf{P}>0.05)$ of rats. However, $\mathrm{FI}$ and $\mathrm{BWG}$ were depressed by prolongation of heating only at $120^{\circ} \mathrm{C}$. In contrast, FC values consequently increased with increasing both temperature and time of heating. Mild heating at $100^{\circ} \mathrm{C}$ for 10 min produced $\mathrm{FC}$ value of 3.25 while excessive heating at $120^{\circ} \mathrm{C}$ for $30 \mathrm{~min}$ raised that value to 4.42 .

A linear decrease $(P \leqslant 0.001)$ in thyroid gland weights was observed as temperature and time of heating of extracted cake increased. Heating at $120^{\circ} \mathrm{C}$ for $30 \mathrm{~min}$ reduced the thyroid weight of rats $30 \%$ below that obtained for the meal heated at $100^{\circ} \mathrm{C}$ for $10 \mathrm{~min}$. The thyroid weights were linearly dependent $(\mathrm{P} \leqslant 0.001)$ on glucosinolate content in heated cake. The weights of rat liver did not differ among groups fed the diets containing cake heated in experimental conditions and ranged from 90 to $95 \mathrm{mg} / \mathrm{g} \mathrm{BW}$.

\section{DISCUSSION}

Cooking and toasting in the oil plant affected content of lysine, available lysine and glucosinolates. It was noted that the decrease of lysine concentration

TABLE 4

Performance of broiler chickens fed with the diets containing rapeseed products obtained from different processing stages (Experiment 2)

\begin{tabular}{lccccc}
\hline Diet with: & Defatted seeds & Defatted cake & RSM & \multirow{2}{*}{ SE } \\
\cline { 3 - 5 } \cline { 3 - 5 } Processing stage: & before heating & after cooking & after toasting & \\
\hline Feed intake, kg/4 weeks & $2.01^{\mathrm{B}}$ & $2.04^{\mathrm{AB}}$ & $2.13^{\mathrm{A}}$ & 0.02 \\
Body weight gain, g/4 weeks & 971 & 960 & 990 & 9.91 \\
Feed conversion, g/g & $2.07^{\mathrm{b}}$ & $2.12^{\mathrm{ab}}$ & $2.15^{\mathrm{a}}$ & 0.01 \\
Thyroid, mg/kg BW & $217^{\mathrm{B}}$ & $284^{\mathrm{A}}$ & $93^{\mathrm{C}}$ & 6.76 \\
Liver, g/kg BW & 22.2 & 22.7 & 23.2 & 0.24 \\
\hline
\end{tabular}

ab differences in rows significant at $P \leqslant 0.05$

${ }^{A B}$ differences in rows significant at $P \leqslant 0.01$ 


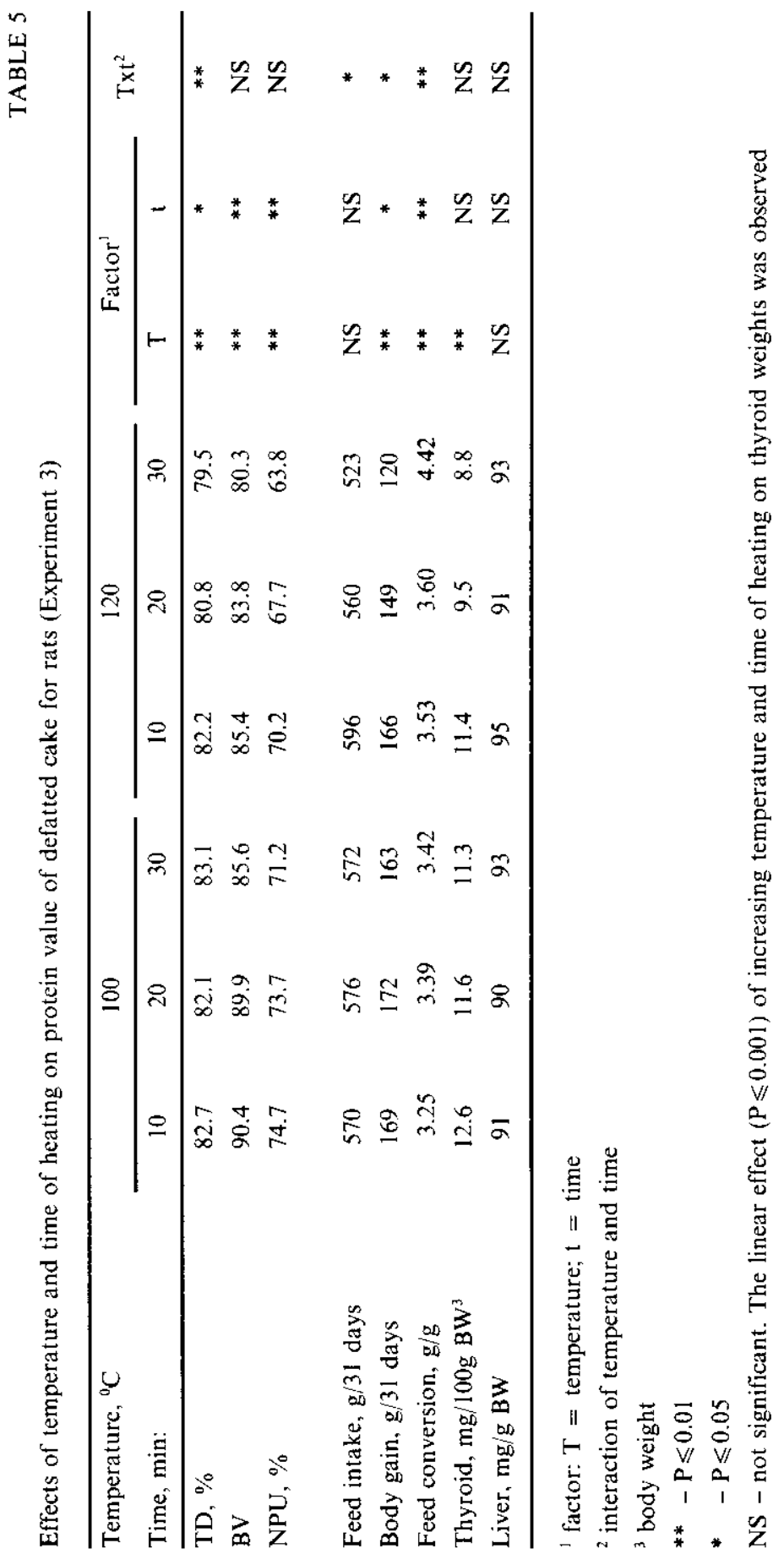


was observed during processes whereas decrease in available lysine and glucosinolate contents occurred only during toasting. The greater damaging effect of toasting than that of cooking on protein quality is in agreement with findings by Buraczewska and Grala (1991) in respect to total and available lysine concentrations, as well as with the results presented by Katzer and Mińkowski (1989) and by Anderson-Hafermann et al. (1993) regarding protein solubility.

Lack of the effect of cooking on glucosinolate content in the cake was probably due to rather low temperature $\left(85^{\circ} \mathrm{C}\right)$. However, during this process enzymatic hydrolysis of glucosinolates to ITC, VOT, nitriles and thiocyanate ion may occur (Niewiadomski, 1990). Dąbrowski et al. (1989) reported that cooking at $95^{\circ} \mathrm{C}$ for $15 \mathrm{~min}$ may decrease the level of glucosinolates by $20 \%$, mainly due to hydrolysis of indole glucosinolates. In our study glucosinolates were measured as equivalent of isothiocyanates (ITC) and vinyl-oxazolidinethiones (VOT), thus, it is not possible to find out whether indole glucosinolates were hydrolysed and/or reduced at the temperature of $85^{\circ} \mathrm{C}$ during cooking. Glucosinolates were reduced during toasting $\left(100^{\circ} \mathrm{C}\right)$ which is in agreement with the observation on rape seed processing by Shires et al. (1983), Dąbrowski et al. (1989), Katzer and Mińkowski (1989).

Protein value (BV and NPU) of cooked defatted cake measured on rats (Expt. 1) was higher than found for defatted seeds and RSM. The protein value of seeds and cake was not directly dependent on total or available lysine concentrations in protein, in contrast to those samples which were heated (autoclaved) in the laboratory (Expt. 3) or to RSM toasted in the oil plant (Grala et al., 1994). Similarly to our study, other authors also showed that mild hydro-thermal treatment of double-low rape seeds increased their biological value (Słomiński et al., 1985; Rakowska et al., 1987; Rotkiewicz, 1991).

Feed intake and rat performance improved as processing progressed, in spite of the decrease of total and available lysine contents, particularly in RSM. That was probably due to the reduction of glucosinolates in the toasted RSM as compared to the non-heated seeds and the cooked cake. In experiment with chickens a beneficial effect of processing stages was noted for FI and thyroid weight. However, a simultaneous deterioration of FC may suggest that chickens were much more sensitive than rats to the reduced lysine content.

It is well known that the level of glucosinolates and active myrosinase in rape seed may have adverse effect on physiological status (thyroid and/or liver enlargement) and/or growth perfomance of animals (Vermorel et al., 1987, 1988; Rotkiewicz, 1991). It was found that the breakdown products of glucosinolates such as VOT, nitriles and thiocyanate ion show goitrogenic effects (Heaney et al., 1987; Macholz et al., 1987; Chichłowska, 1990). Besides, it was established that intact glucosinolates may be hydrolysed in the digestive tract of animals by bacteria enzymes which possess myrosinase-like activity (Campbell et al., 1987; 
Diedrich and Kujawa, 1987; Rotkiewicz et al,, 1987; Słominski et al., 1988; Nugon-Baudon et al., 1990). Nitriles (up to $95 \%$ of total products) and thiocyanate ions (Campbell and Słominski, 1989) are mainly formed as a result of the microbiological hydrolysis of glucosinolates. May be that such products were responsible for the great enlargement of thyroid glands of rats fed the diet with defatted cake found in our study. Similar results were reported by Paik et al. (1981) who assumed that nitriles present in autolysed raw or cooked meal are much more toxic than goitrin (VOT). In the present study, the observed worse performance of animals fed non-heated seeds or the cooked cake than those fed the toasted RSM could be due to the above-mentioned factors since cooking in plants is not sufficient to inactivate myrosinase while toasting is effective (Shires et al., 1983; Kozłowska et al., 1983; Katzer and Mińkowski, 1989).

The results of Experiment 3 showed that increasing both temperature and time of toasting decreased protein value of the heated cake. These results confirmed findings obtained in the study by Grala et al. (1994) who showed that increasing toasting temperature from 90 to $100^{\circ} \mathrm{C}$ markedly decreased protein value of RSM, especially the content of total and available lysine as well as the apparent ileal digestibility of protein and amino acids, $\mathrm{N}$ utilization and pig performance. In the present study the protein quality (TD, BV, NPU) and growth performance of rats (FC, BWG) decreased as lysine and available lysine contents in protein was reduced. BV was highly correlated with the concentration of available lysine in the heated cake $(r=0.87, P \leqslant 0.001)$.

These results correspond very well with the earlier studies where increasing temperature and time of rape seed heating resulted in a decrease of nutritional value of protein and of animal performance (Rakowska et al., 1987; Pastuszewska and Rakowska, 1989; Rotkiewicz, 1991) The negative effects of temperature and time of heating on total and available lysine concentrations and reduced lysine and $\mathrm{N}$ utilization by rats is due to Maillard reaction (Hurrell, 1990). The extent of protein damage during Maillard reaction depends on time and temperature of heating and such constituents of the seed as free sugars (Pickard et al., 1986), moisture, tannin, ITC and VOT (Björkman, 1973, cited by Rotkiewicz, 1991).

The protein value (BV, NPU) of defatted cake determined in a short time balance experiment was high, but the growth performance (FI, BWG) of rats fed the same diet for longer period was poor and similar to that observed for overheated cake $\left(120^{\circ} \mathrm{C}\right.$ for $\left.30 \mathrm{~min}\right)$. The results suggest that both insufficient toasting and overheating may affect animal performance negatively, but in each case the reason of poor performance may be different. In growth performance trial the results are mainly limited by factors restricting feed intake such as glucosinolates and their breakdown products (ITC, VOT, nitriles), while in short $\mathrm{N}$ balance trial results are affected by factors strictly related to digestibility and 
quality of protein and availability of lysine. This is in agreement with the results of the previous study by Grala et al. (1994) with pigs.

The laboratory toasting at $100^{\circ} \mathrm{C}$ for 10 or $20 \mathrm{~min}$ did not decrease protein value, but probably inactivated myrosinase what can be concluded from observations or rats showing smaller thyroid weight as compared to animals fed defatted seeds or defatted cake. That confirms the results of Rakowska et al. $\left(1987\right.$; 1989) who reported that heating at $100^{\circ} \mathrm{C}$ for $10 \mathrm{~min}$ inactivated myrosinase completely without negative effect on the biological value of protein. As a result, the performance of rats fed the cake heated at $100^{\circ} \mathrm{C}$ was better than the other, not heated rapeseed products.

\section{CONCLUSIONS}

Experiments with the use of rapeseed meal heated at various temperature and time duration and with the rapeseed products coming from consecutive processing stages showed that mild toasting (at $100^{\circ} \mathrm{C}$ for 10 or $20 \mathrm{~min}$ ) is beneficial to the nutritional value of the double-low rapeseed meal. Both the lack of toasting and overheating affect negatively performance of rats and chickens.

\section{REFERENCES}

Anderson-Hafermann J.C., Zhang Y., Parsons C.M., 1993. Effects of processing on the nutritional quality of canola meal. Poultry Sci. 72, 326-333

Booth V.H., 1971. Problems in the determination of FDNB-available lysine. J. Sci. Food Agric. 22, 658-666

Buraczewska L., Grata W., 1991. Determination of available lysine in feedstuffs treated with high temperature is necessary. Short communication: XXII Symp. Commission of Animal Nutrition, Committee of Animal Sciences, Polish Acad. Sci., Bydgoszcz, Poland

Byczyńska B., 1971. The isothiocyanates and oxazolidinethiones determination in rape seeds. Biul. IHAR 5, 57-67 (in Polish)

Campbell L.D., Słominski B.A., 1989. Further studies on the sources of thiocyanate ion in the excreta of poultry fed low-glucosinolate rapeseed (Brassica napus) meal. J. Sci. Food Agric. 47, 61-73

Campbell L.D., Slominski B.A., Stanger N.E.. 1987. Influence of caecectomy and dietary antibiotics on the fate of ingested intact glucosinolates in poultry. In: Proc. 7 th Int. Rapeseed Congress, Poznań, Poland, Vol. 7, 1704-1709

Chichlowska J., 1990. Effect of antimetabolic factors from post-extraction rapeseed meals on selected hormones and physiological indices in rats and swine. Roczn. AR, Poznań, Rozpr. Nauk. No. 205 (in Polish)

Diedrich M., Kujawa M., 1987. Degradation of progoitrin and breakdown product VOT by microorganisms of intestine of rats in vitro. In: Proc. 7th Int. Rapeseed Congress, Poznań, Poland, Vol. 7, 1710-1716

Dąbrowski K.J., Rutkowski A., Mamimanna S.G., Rowicka A., 1989. The reduction of glucosinolate and sinapine contents, under industrial processing of rapeseed. Fat Sci. Technol. 9, 361-363 
Grala W., Buraczewska L., Gdala J., Pastuszewska B., 1994. Effect of thermal processing on the protein value of double-low rapeseed products. 1. Effect of toasting temperature on protein value of rapeseed meal for pigs. J. Anim. Feed Sci. 3, 33-42

Heaney R.K., Fenwick G.R., 1987. Identifying toxins and their effects: glucosinolates. In: D.H. Watson (Editor). Natural Toxins in Food. Progress and Prospects, pp. 76-109

Hurrell R.F., 1990. Influence of the Maillard reaction on the nutritional value of foods. In: P.A. Finot, H.U. Aeschbacher, R.F. Hurrell (Editors). The Maillard Reaction in Food Processing, Human Nutrition and Physiology. Birkhaüser Verlag, Basel, Switzerland, pp. 245-258

Katzer A., Minkowski K., 1989. Observations of the commercial double-low rape seeds processing. Thuszcze jadalne 37 (4), 20-30 (in Polish)

Kozlowska H., Nowak H., Nowak J., 1983. Characterization of myrosinase in Polish varieties of rapeseed. J. Sci. Food Agric. 34, 1171-1178

Macholz R., Ackermann H., Dierich M., Henschel K.P., Kujawa M., Lawerenz H.J., Przybilski H., Schnaak W., Schulze J., Woggon H., 1987. Studies on the degradation of glucotropaeolin and progoitrin - toxicity and reactivity of splitting products. In: Proc. 7th Int. Rapeseed Congress, Poznań, Poland, Vol. 7, 1641-1646

National Research Council., 1967. Evaluation of protein quality. Publ. No 1100, Nat. Acad. Sci., Washington, DC

Niewiadomski H., 1990. Developments in Food Science 23. Rapeseed - Chemistry and Technology. Elsevier Amsterdam-Oxford-New York-Tokyo, PWN - Polish Sci. Publ., Warsaw

Nugon-Baudon L., Rabot S., Wal J.-M., Szylit O., 1990. Interaction of the inestinal microflora with glucosinolates in rapeseed meal toxicity: first evidence of an intestinal Lactobacillus possessing a myrosinase-like activity in vivo. J. Sci. Food Agric. 52, 547-559

Paik I.K., Robblee A.R., Clandinin D.R., 1981. The effect of heat treatment and enzyme hydrolysis of rapeseed meal on the performance of broiler chickens. Can. J. Anim. Sci. 61, 181-189

Pastuszewska B., Rakowska M., 1989. The improvement of the nutritional value of double-low rapesced oil meal by the proper technology of production. Zesz. probl. IHAR, Rośl. Oleiste, Vol. 1, 350-362 (in Polish)

Pickard M.D., Youngs C.G., Wetter L.R., Boulter G.S., 1986. Processing of canola seed for quality meal. In: D.R. Clandinin (Editor). Canola Meal for Livestock and Poultry. Canola Council of Canada, Publ. 59, 3-4

Rakowska M., Zalińska M., Słominska E., Byczyńska B., 1987. Effect of heat treatment on lysine and protein availably of low glucosinolate rapesecd meal in rats. In: Proc. 7th Int. Rapeseed Congress, 11-14 May 1987, Poznań, Poland, Vol. 7, 1722-1726

Rakowska M., Kupiec R., Sawicki J., 1989. Available lysine content as an indicator of changes of biological value of double-low rapeseed protein. Zesz. probl. IHAR, Rośl. oleiste, Vol. 1, 100-109 (in Polish)

Rotkiewicz D., 1991. Inactivation of myrosinase in rape seeds as a way to improve quality of meal and oil. Acta Acad. Agricult. Tech. Olst., Technologia Alimentarum, No 23, Suppl. A (in Polish)

Rotkiewicz D., Kozłowska H., Smulikowska S., 1987. Changes of rapeseed glucosinolates in digestive tract of hen. In: Proc. 7th Int. Rapeseed Congress, Poznań, Poland, Vol. 7, 1698-1703

Shires A., Bell J.M., Blair R., Blake J.A., Fedec D., McGregor D.I., 1983. The feeding value canola meal for broiler chickens as affected by heat and steam during desolventation and by fibre reduction. Research on Canola Seed, Oil, Meal and Meal Fractions. Canola Council of Canada, Winnipeg, Manitoba 61, 12-16

Stominski B.A., Campbell L.D., Stanger N.E., 1988. Extent of hydrolysis in the intestinal tract and potential absorption of intact glucosinolates in laying hens. J. Sci. Food Agric. 42, 305-314 
Slominski B.A., Zalińska M., Slominska E., Rakowska M., 1985. Nutritional value of low - glucosinolate rapeseed oil processed in different toasting conditions. Hod. Rośl. Aklim. Nasien. 29, 7-12 (in Polish)

Vermorel M., Davico M-J., Evrard J., 1987. Valorization of rapeseed meal. 3. Effects of glucosinolate content on food intake, weight gain, liver weight and plasma thyroid hormone levels in growing rats. Reprod. Nutr. Develop. 27, 57-66

Vermorcl M., Heaney R.K., Fenwick G.R., 1988. Antinutritional effects of the rapeseed meals, Darmor and Jet Neuf, and progoitrin together with myrosinase, in the growing rat. J. Sci. Food Agric. 44, 321-334

\section{STRESZCZENIE}

Wpływ procesów termicznych na wartość pokarmową biakka z rzepaku podwójnie ulepszonego. 2. Wplyw etapów odolejania przemyslowego i tostowania w warunkach laboratoryjnych

W doświadczeniu bilansowym i wzrostowym na szczurach oraz wzrostowym na kurczętach oznaczono wpływ kolejnych etapów odolejania rzepaku w warunkach przemysłowych (prażenie i tostowanie), porównując wartość białka nasion surowych, wytłoku poddanego prażeniu w temp. $85^{\circ} \mathrm{C}$ i śruty tostowanej w temp. $100^{\circ} \mathrm{C}$. Określono także wplyw temperatury $\left(100\right.$ i $\left.120^{\circ} \mathrm{C}\right)$ oraz czasu $(10,20$ i $30 \mathrm{~min})$ ogrzewania wytloku w warunkach laboratoryjnych na wartość odżywczą białka w testach na szczurach. Kryterium wartości odżywczej produktów rzepakowych była zawartość lizyny ogólnej i lizyny dostępnej, zawartość glukozynolanów oraz wyniki doświadczeń bilansowych i wzrostowych na szczurach i wzrostowych na kurczętach-broilerach.

Zawartość lizyny ogólnej obniżała się pod wpływem prażenia i tostowania, natomiast na lizynę dostępną i glukozynolany miało wpływ glównie tostowanie. Strawność białka nasion, wytłoku i śruty nie różniła się, zaś wartość biologiczna bialka wytloku byla większa niż nasion i nie różnila się od śruty. Przyrosty szczurów otrzymujących pasze z kolcjnych etapów odolejania zwiększyly się, natomiast kurczęta we wszystkich grupach przyrastały podobnie.

Wykazano, że zarówno temperatura jak i czas ogrzewania w warunkach laboratoryjnych powodują̧ istotne $(P \leqslant 0.001)$ zmniejszanie zawartości lizyny ogólnej i dostępnej. Zmniejszonej zawartości obu form lizyny w białku towarzyszyło obniżenie wartości biologicznej białka (BV i NPU) oraz ograniczenie wzrostu szczurów.

Nieprawidłowy proces tostowania może mieć ujemny wpływ na wartość odżywczą bialka rzepaku, jednak lagodne tostowanie $\left(100^{\circ} \mathrm{C}\right.$ przez 10 lub $\left.20 \mathrm{~min}\right)$ jest konieczne, gdyż samo prażenie przed ekstrakcją oleju nie zapewnia wyeliminowania szkodliwego działania substancji antyżywieniowych. 